\title{
System of metaphoric models in Russian and American disability mass media discourse
}

\author{
I. A. Kurbanov \\ Department of Teaching English and Interpreting \\ Methodology \\ Surgut State University \\ Surgut, Russia \\ ibragimkurbanov@mail.ru
}

\author{
S.G. Noskova \\ Department of Teaching English and Interpreting \\ Methodology \\ Surgut State University \\ Surgut, Russia \\ noskova@slib.ru
}

\begin{abstract}
In the study of contemporary political discourse there is a new, little-known, topical direction, which is the analysis of modelling the conceptual metaphor of an image of a person with disabilities. Disability issues, like gender, race and any other social equality issue, are of great importance. Human prejudice, stereotypes, ignorance hinder us from understanding the problems of the disabled who frequently suffer bad attitudes and exclusion. Mass Media have a great power to promote the positive image of a person with disability. Over time, attitudes towards people with disability have changed greatly from a stigma (when "criple" was considered as evil because of his/her disability) to medical model (with scientific advances in medicine and other fields) in the $18^{\text {th }}$ and $19^{\text {th }}$ centuries, to a sociopolitical model in the mid-twentieth century, up to the present SOCIAL MODEL where a person with a disability is an active participant in all spheres of life. The authors are doing cognitive, contextual and discursive analyses of four types of metaphors: naturomorphic, antropomorphic, sociomorphic and artefact metaphors examining the articles of popular magazines and newspapers of Russia and the USA to compare and distinguish universal and peculiar national features in representation of disability mass media discourse of the two countries. The research is based on Lakoff's theory on cognitive metaphor, which is considered as the core of human thinking, and on works of Russian linguists (Baranov, Kubryakova, Karaulov and others). This article classifies the models according to their source-spheres and distinguishes the models which have necessary criteria for comparative analyses.
\end{abstract}

Keywords- disability, disability discourse, metaphoric modeling of disability, disability mass media discourse, source (base) metaphoric model

\section{INTRODUCTION}

In the course of the comparative analysis of Russian and American disability discourse, the authors have distinguished the following typical models according to a source-sphere of the metaphoric borrowing: "disability is physiology", "disability is economy", "disability is socializing", "disability is education", "disability is a war", "disability is a wildlife", "disability is an nonliving nature", "disability is new technologies", "disability is politics", disability is law ".

\section{THE SYSTEM OF METAPHORIC MODELS IN RUSSIAN AND AMERICAN DISABILITY DISCOURSE}

The quantitative characteristics of the system of the metaphoric MODELS functioning in disability-discourse of Russia and the USA are presented in the table. (Table 1).

TABLE I. THE SYSTEM OF METAPHORIC MODELS IN RUSSIAN AND AMERICAN DISABILITY DISCOURSE

\begin{tabular}{|c|c|c|c|c|c|}
\hline & \multirow{2}{*}{$\begin{array}{c}\text { Base } \\
\text { spheres of } \\
\text { the } \\
\text { metaphoric } \\
\text { expansion } \\
\text { into target } \\
\text { sphere } \\
\text { "Disability } \\
\text { "? }\end{array}$} & \multicolumn{2}{|c|}{$\begin{array}{l}\text { Russian disability } \\
\text { discourse }\end{array}$} & \multicolumn{2}{|c|}{$\begin{array}{l}\text { American disability } \\
\text { discourse }\end{array}$} \\
\hline & & $\begin{array}{l}\text { Number of } \\
\text { metaphoric } \\
\text { units (MU) }\end{array}$ & $\begin{array}{c}\text { Percentage } \\
\%\end{array}$ & $\begin{array}{l}\text { Number of } \\
\text { metaphoric } \\
\text { units (MU) }\end{array}$ & $\begin{array}{c}\text { Percentage } \\
\%\end{array}$ \\
\hline 1. & Socializing & 483 & 28 & 468 & 24 \\
\hline 2. & Physiology & 479 & 27 & 415 & 22 \\
\hline 3. & $\begin{array}{c}\text { New } \\
\text { technology }\end{array}$ & 181 & 10 & 206 & 12 \\
\hline 4. & Economics & 154 & 10 & 242 & 12,4 \\
\hline 5. & War & 89 & 5 & 50 & 3 \\
\hline 6. & $\begin{array}{c}\text { Non-living } \\
\text { nature }\end{array}$ & 70 & 4 & 27 & 1 \\
\hline 7. & Wildlife & 67 & 3.8 & 28 & 1.2 \\
\hline 8. & Law & 67 & 3.8 & 130 & 6 \\
\hline 9. & Education & 42 & 2.4 & 150 & 7 \\
\hline 10 & Literature & 36 & 2,8 & 33 & 2 \\
\hline 11 & Family & 33 & 1,9 & 74 & 4 \\
\hline 12 & Religion & 21 & 1 & 7 & 0.4 \\
\hline 13 & Politics & 7 & 0.3 & 90 & 5 \\
\hline & TOTAL & 1729 & 100 & 1920 & 100 \\
\hline
\end{tabular}

The following models have proved to be the most productive and detailed in Russian as well as American disability discourse: "Disability is Socializing", "Disability is Physiology", «Disability is new technology», "Disability is Economics", "Disability is war", "Disability is Nonliving 
nature", "Disability is Wildlife", "Disability is Law", "Disability is Education", "Disability is Politics".

The research shows that the most frequently used basespheres of the metaphoric expansion into the target sphere are: "Socializing" - 483 images (28\%), "Physiology" - 479 images (27\%), "New technology" - 181 images (10\%), "Economics" - 154 images (10\%), "War" - 89 images (5\%) out of 1729 metaphoric units. Having analyzed American disability discourse, the authors have distinguished the most frequently used conceptual base spheres. They are: "Socializing" - 468 images (24\%), "Physiology" - 415 images $(22 \%)$, "Economics" -242 images $(12,4 \%)$, "New technology" - 206 images (12\%), "Education" - 150 images (7\%), "War" - 50 images (3\%), "Politics" - 90 images $(5 \%)$ out of 1920 metaphoric units.

The following figure compares the data to a greater extent.

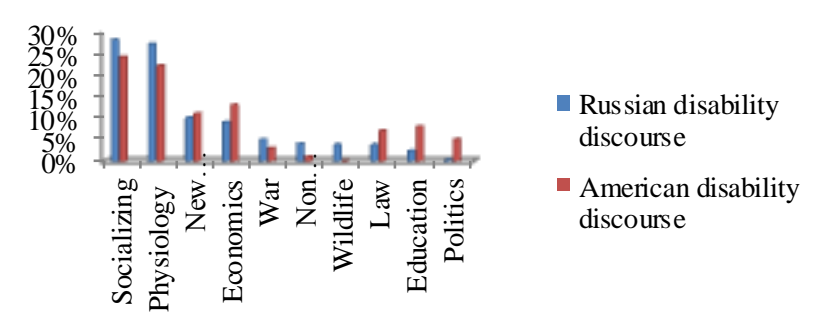

Fig. 1. The most frequent base spheres of metaphoric expansion into target sphere "Disability" in Russian and American disability discourse (as a percentage \%).

The frequency of these conceptual fields is specified by the national discourse peculiarities of both countries.

The metaphoric models "Disability is Socializing", "Disability is Physiology", "Disability is New technology", "Disability is Economics" have proved to be frequent, nationally universal, dominant, updated in Russian and American disability discourse. Apart from these, it is necessary to distinguish metaphoric models "Disability is War" in Russian discourse and "Disability is Law", "Disability is Education", "Disability is Politics" in American disability discourse. As these metaphoric models possess nationally-specific qualities and reflect peculiarities of state development, let us consider the fact that their linguistic and cultural peculiarities deserve a closer examination and comparison in this research paper. Upon closer analysis, let us consider the following metaphoric models "Disability is Nonliving nature" and "Disability is Wildlife" updated in the Russian and American disability discourse. Additionally they possess a bright emotive coloring and thus produce other double meanings, which is important for the disability representation. All these mentioned criteria allow the inclusion of the presented models into the comparative research. The authors do not include the metaphoric models "Disability is Literature" and "Disability is Religion" as they are not frequently used in Russian and American mass media disability discourse.

While comparing and analyzing Russian and American disability discourse we differentiated four main categories of disability metaphors. We considered several typical models in each of these categories. These models do not cover all the complexity of metaphoric expansion sources but give a fuller comprehension about the specifications of each category.

Natural metaphors are presented through the following metaphoric models: 1) "Disability is Wildlife", where the base concepts are primary power elements (land, air, fire, water) and "space"; 2) "Disability is Wildlife", where the following key concepts are actualized: "animal", "predator», «assistant animal», "one-celled", "survival", "plant", "vegetable", "subhuman" which on the whole present a negative image of a person with disability.

The natural metaphor is considered prototyped metaphor (paradigm). Addressing this kind of metaphor is fully justified as a human is a part of nature, he is surrounded by nature and he is influenced by natural climate factors. Rich textual research material is explained by the previous development of human society, those epochs when animalism was considered the base of the world's formation. But taking into account the paradigm of attitudes towards disabilities (presented in the first paragraph of the chapter), this category of metaphors characterizes the base, initial stage - period of stigma - from the Latin - "label" - explaining disabilities as a punishment for the sins which excludes a person from society which, consequently, have unacceptable discriminative characteristics in a larger part of the presented metaphors.

The next stage in shifting and change in paradigms according to the research made by Baglieri S., Shapiro A. and classification of A. P. Chudinov, which changed the behavioral image of a person with a disability from "amoral" to "ill". This was a great breakthrough for the world of the disabled.

Antropomorphic metaphor. The disability sphere as well as political reality is constructed according to the image and to the resemblance of a man. The antropomorphic metaphor is carried out in the metaphoric model "Disability is Physiology", where we exploit the following instant concepts: "human body", "physiological organs", "diseases and phobias", "disease characteristics", "physiological peculiarities", "emotions", "personality features", "death". While comparing the disability mass media discourse of both countries, the authors have singled out similarities and differences. Both discourses express the pain and sincere deep emotions of the problem. As for the peculiar features, the authors pointed out the accuracy in facts and fugures, thorough scientific investigations when explaining disability issues, suggesting solutions or analyzing the moral spiritual development of a person in concern in American mass media discourse while the Russian media (journalists) are mainly trying to avoid scientific details replacing diagnoses with simple common language.

The complex analysis of thematically connected categories of naturomorphic and antropomorphic metaphors reflects the initial stages (stigma-process and scientific explanation) in development of disability issues.

The modern stage in developing the attitudinal paradigm towards disability encourages the equal inclusion of people with disabilities into all social spheres of life. This claim is 
fulfilled through the presented in the national awareness artefact and sociomorphic metaphors which are interrelated with each other and deserve closer examination.

Artefact metaphor finds its way through the model "Disability is New Technology", within the frame in which the following concepts have been actualized: "Technology", "IT-technology", "assistive technology", "accessible environment", "bionic people". They make the image of a person with disabilities popular, futuristic, and a person to look up to.

Sociomorphic metaphors embrace different spheres of social life. This metaphoric category finds its actualization in the metaphoric models: 1) "Disability is Socializing", where one can exploit such fundamental concepts as "inclusion") (mainstreaming the disabled into full sociopolitical life, leisure, sports, travelling fashion, etc, which consequently present frames of this model) and "exclusion»" (elimination from social life which is considered unacceptable - violation of human rights and freedom - a sign of ableistic society). Thus the concept "inclusion" is meaningful in disability socializing. This frame has proven to be the most productive, dominant and frequent in all metaphor models as it covers 148 metaphoric units comprising $28 \%$ in Russian and 204 metaphoric units $-34 \%$ in American disability mass media discourse. The structure of this frame is presented through the following slots: "Fashion", "Sports", "Employment",,'Theatre", "Family", "Dances", "Travelling”.

The frame «Disability is exclusion» is not frequent in the metaphoric model "Disability is Socializing" (55 MU in Russian and 34 MU in American disability mass media discourse, constituting $14 \%$ and $7 \%$ respectively from the total sum of metaphors within this MM). But it is very important for this research as it aims at fighting the negative representation of a person with a disability and connecting with the prohibited by the UN Convention on Human rights ableistic opinions on society.

\section{CONCLUSION}

To conclude, the metaphoric model "Disability is Socializing" has proved to be not only the most frequent (comprising about $20 \%$ of all models), but the most productive and dominant - TOPICAL model in Russian and American disability mass media discourse. It is fully justified in the history and philosophy of Russian and American societies as the modern stage of social development puts the SOCIAL MODEL first for solving the problems of persons with disabilities.

Upon closer examination, the authors have discovered some national peculiarities. For the Russians, the most important spheres for socializing of the disabled are Fashion, Sports and Employment. The following social spheres as Fashion, Family, Sports and Emloyment take over in the national consciousness of American people, maintaining the qualitative socializing of the disabled. There is no doubt that two spheres - Fashion and Sports - are the most representative in the disability mass media discourse of both countries, in which people with disabilities are shown as the brightest characters, thus, promoting an inclusive society as well as inspiring and encouraging people for socially significant actions and disability awareness.

\section{References}

[1] S. Baglieri, A. Shapiro, Disability studies and the inclusive classroom: Critical practices for creating least restrictive attitudes, Routledge, 2012, $286 \mathrm{p}$.

[2] A.P. Chudinov, Metaphoric mosaic in contemporary political communication, Ekaterinburg: Ural state pedagogical university, 2003, $248 \mathrm{p}$.

[3] M. Dahl, "The role of the media in promoting images of disability disability as metaphor: The evil crip," Canadian Journal of Communication, vol. 18(1). Retrieved September 2009 from http://www.cjc-online.ca/index.php/journal/article/viewArticle/718/624. 